\title{
PCR-based diagnosis for Chagas' disease in Bolivian children living in an active transmission area: comparison with conventional serological and parasitological diagnosis
}

\author{
P. WINCKER ${ }^{1,2 *}$, J. TELLERIA ${ }^{3}$, M. F. BOSSENO ${ }^{3}$, M. A. CARDOSO ${ }^{1}$, P.MARQUES ${ }^{1}$, \\ N. YAKSIC ${ }^{4}$ C. AZNAR ${ }^{5}$, P. LIEGEARD ${ }^{5}$, M. HONTEBEYRIE ${ }^{5}$, F. NOIREAU \\ C. M. MOREL ${ }^{1}$ and S. F. BRENIERE \\ ${ }^{1}$ Laboratorio de Biologia Molecular e Doenças Endêmicas, Departmento de Bioquimica e Biologia Molecular, Instituto \\ Oswaldo Cruz, Fundafao Oswaldo Cruz, Av. Brasil 4365, 21045-900 Rio de Faneiro, Brazil \\ ${ }^{2}$ Laboratoire Génome des Parasites, Parasitologie, Faculté de Médecine, 163 rue Auguste Broussonet, 34000 Montpellier, \\ France \\ "UR41, UMR ORSTOM/CNRS 9926 "Génétique moléculaire des Parasites et des Vecteurs", CP 9214, La Paz, \\ Bolivia \\ ${ }^{4}$ Universidad mayor de San Andres, IBBA, CP 641, La Paz, Bolivia \\ ${ }^{5}$ Institut Pasteur, Département d'Immunologie et Centre de Biologie médicale, 28 rue du Dr Roux, 75724 Paris Cedex 15, \\ France

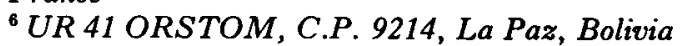

(Received 9 fuly 1996; revised 30 September 1996; accepted 1 October 1996)

\section{SUMMARY}

A large field study has been performed in the Cochabamba region of Bolivia with the aim of comparing the polymerase chain reaction (PCR) with other diagnostic methods for Chagas' disease. The amplification of Trypanosoma cruzi-specific kinetoplast DNA sequences in blood samples was compared with classical serological methods, specific IgM detection and direct parasite visualization for $\mathbf{2 6 8}$ school children in a single village where Chagas' disease transmission is active. Of 113 children positive by classical serology or buffy coat examination, 106 were detected by PCR (sensitivity: $93.8 \%$ ). We did not observe any significant difference of PCR sensitivity between initial (IgM and/or buffy coat positive) and indeterminate stage (only IgG positive) patients. Among the remaining 155 children unconfirmed as chagasic (who were either only IgM positive, IgG-, IgM-, and buffy coat -negative) only 1 case was PCR positive. This case may be due to DNA contamination, or to a very recent infection not detected otherwise, or to specific immune depression. These results show that PCR is a very sensitive parasitological test for Chagas' disease in active transmission regions. The future follow-up of the possibly infected patients who were only IgM-positive should clarify the interest of PCR and IgM tests in the detection of starting infections.

Key words: Trypanosoma cruzi, Chagas' disease, PCR diagnosis, serological diagnosis.

\section{INTRODUCTION}

The protozoan parasite 'Trypanosoma cruzi is the aetiologic agent of Chagas' disease, a very important public health problem in Latin America. It is transmitted by triatomine bugs during their blood meals. Albeit an important control programme has been started some years ago to eliminate the domiciliary species of triatomines, many regions in Latin America still have an active transmission cycle due to economic difficulties in implementing it (Moncayo, 1993). Consequently, sensitive methods for Chagas' disease diagnosis are particularly important in these poorest regions to precisely assess the rate of infection and the impact of future control programmes.

* Corresponding author: Laboratoire Génome des Parasites, Parasitologie-Faculté de Médecine, 163 rue Auguste Broussonet, 34000 Montpellier, France. Tel: +334676355 13. Fax: +33467630049 .
The diagnosis of Chagas' disease relies primarily on serological techniques. However, these techniques present many problems of specificity (Camargo, 1992). An additional problem that occurs in regions of active transmission is the failure of the traditional serological methods, based on the detection of anti-T. cruzi $\mathrm{IgG}$, to detect recent infections. To circumvent these difficulties, it has been suggested that serological diagnosis may be complemented by an efficient parasitological method. These methods include the xenodiagnosis, the haemoculture and the direct microscopical examination of fresh blood (Chiari et al. 1989). The specificity of these techniques is high, but unfortunately their sensitivities cannot be compared to that of serology, due to the low parasite concentration in the blood of chagasic patients, principally during the chronic phase of the disease. Recently, the definition of different PCR amplification methods for detecting low quantities of 
T. cruzi DNA have led to the hope of a new, highly sensitive parasitological technique for Chagas' disease diagnosis (Moser, Kirchoff \& Donelson, 1989; Sturm et al. 1989; Taibi et al. 1995).

A series of recent studies have focused on the use of PCR amplification of kinetoplast DNA sequences in the diagnosis of chronic chagasic patients in different regions of Brazil (Avila et al. 1993; Wincker et al. $1994 a$; Britto et al. $1995 a, b$; Junqueira, Chiari \& Wincker, 1996). They have shown that this technique can be almost $100 \%$ specific, and that its sensitivity can reach $45-96.5 \%$ as compared with serology. Most importantly, direct comparisons were performed with xenodiagnosis or haemoculture during these studies. In every case, the PCR proved to be a markedly more sensitive method (Wincker et al. 1994a; Britto et al. 1995 a; Junqueira et al. 1996). The main limit observed with PCR was that its sensitivity never reached that of serology. A semiquantitative analysis of these results showed that this was due to the very low concentration of $T$. cruzi in the blood of chronic patients in some particular regions, and that this probably reflects the genetic constitution of the parasite strains circulating there (Britto et al. $1995 b$; Junqueira et al. 1996). It is therefore clear that the main use of PCR in Chagas' disease diagnosis is to complement serological methods.

Another application of PCR can be found in active transmission areas, where acute and chronic cases co-exist. As the most recently infected individuals generally have a high parasitaemia, but present a delay in raising their antibody response, it may be hypothesized that PCR could be useful in this situation. A preliminary study made with 45 children in Bolivia revealed a high correlation of PCR and $\operatorname{IgG}$ serology in these cases and confirms that PCR can detect chagasic individuals with a negative IgG serology (Wincker et al. 1994b). In the present work, we analysed a large number of children from this endemic area of active transmission, and compared the PCR and IgG serology results with other methods used to diagnose recent infections.

\section{MATERIALS AND METHODS}

\section{Patients and sera}

The individuals examined in this study were children (free of treatment) living in Mizque village located in a highly endemic region of Bolivia (Cochabamba department). The blood samples were collected at the same time, mainly in the elementary school. The average age was $7 \cdot 7$ years old ranging from 1 to 15 years old. None of these children presented clinical symptoms of acute-phase illness. Ten $\mathrm{ml}$ of blood were collected from each child and $5 \mathrm{ml}$ of it were immediately mixed with an equal volume of $6 \mathrm{M}$ guanidine $\mathrm{HCl} / 200 \mathrm{~mm}$ EDTA, pH 8 (Avila et al. 1991). The remaining blood was processed for parasite visualization in the buffy coat (BC test; La Fuente, Saucedo \& Urgel, 1984) and serum preparation.

\section{Serological techniques}

Specific anti-T. cruzi IgG were detected in 4 assays. First, haemagglutination (HEMAVE test, Polychaco, Buenos Aires, Argentina) was carried out in the field. Second, immunofluorescence was performed according to Alvarez, Cerisola \& Rohweder (1968) at the IBBA, La Paz, using T. cruzi epimastigotes fixed by $1 \%$ glutaraldehyde, and a mouse FITClabelled anti-human $\operatorname{IgG}(\mathrm{H}+\mathrm{L})$ conjugate (Biosys, Compiegne, France) diluted 1/200. A detection limit of $1 / 32$ was selected. Finally, enzyme-linked immunosorbent assay (ELISA) was performed in 2 different laboratories (IBBA, La Paz and Institut Pasteur, Paris) according to previous studies (Brenière et al. 1984; Aznar et al. 1995). The sheep peroxidase-conjugated anti-human $\operatorname{IgG}(\mathrm{H}+\mathrm{L})$ used in IBBA, was from Biosys (Compiegne, France) and used at a dilution of $1 / 2500$. The goat $F\left(a b^{\prime}\right)_{2}$ alkaline phosphatase-conjugated anti-human IgG used in Institut Pasteur was from Caltag (San Francisco, USA) and diluted 1/4000. Sera were diluted $1 / 200$ in both cases and the limit extinction values of ELISA and optical density ratio were 0.2 and 1.00 respectively. The diagnosis was based on positivity or negativity of 3 out of 4 tests. Moreover, specific IgM antibodies were detected by ELISA technique in the Institut Pasteur using the $T$. cruzi antigen as previously described (Aznar et al. 1995). The antigen was diluted to a final concentration of $2.5 \mu \mathrm{g} / \mathrm{ml}$ in PBS ( $\mathrm{pH} \mathrm{7.2)}$ ). It was successively incubated with sera diluted 1/200 and goat $F\left(a b^{\prime}\right)_{2}$ peroxidase-conjugated anti-human IgM (Diagnostic Sanofi Pasteur) diluted 1/2000.

\section{$D N A$ extraction and PCR conditions}

The tubes containing the guanidine-EDTA-blood lysates were immersed for $15 \mathrm{~min}$ in a boiling water bath to split the kDNA network (Britto et al. 1993). They were cooled to room temperature, and two $100 \mu 1$ aliquots were taken for DNA preparation. These aliquots were extracted once with phenolchloroform and once with chloroform, and then precipitated with 2 volumes of ethanol in $100 \mathrm{~mm}$ sodium acetate. After centrifugation, the pellets were resuspended in $50 \mu \mathrm{l}$ of distilled water.

The amplifications were carried out in a final volume of $75 \mu \mathrm{l}$ using the hot-start procedure with a solid paraffin barrier separating the oligonucleotides and the Taq polymerase (Chou et al. 1992). The lower solution consisted of $5 \mu \mathrm{l}$ of Taq polymerase reaction buffer (100 mM Tris- $\mathrm{HCl}, \mathrm{pH} \mathrm{8.3,500} \mathrm{mM}$ $\mathrm{KCl}), 7 \cdot 2 \mu \mathrm{l}$ of a dNTPs mixture (10 mM each), $13.5 \mu \mathrm{l}$ of $25 \mathrm{mM} \mathrm{MgCl}$, $200 \mathrm{ng}$ of the T. cruzispecific primers ( $5^{\prime}$ AAATAATGTACGGG(T/G)- 
Table 1. PCR-based diagnosis: comparison with conventional tests (BC = Buffy coat test $; \operatorname{IgG}=$ specific anti-Trypanosoma cruzi immunoglobulins $\mathrm{G}$; $\operatorname{IgM}=$ specific anti- $T$. cruzi immunoglobulins $\mathrm{M}$; confirmed chagasic patients are patients with $\mathrm{BC}$ and/or IgG tests positive.)

\begin{tabular}{lrrr}
\hline \hline Patients (number) & IgG & IgM & PCR \\
\hline Confirmed chagasic (113) & & & \\
$\quad$ With positive BC test & & & \\
$\quad$ No. positive & 9 & 3 & 11 \\
$\quad$ No. negative & 3 & 9 & 1 \\
With negative BC test & 101 & 15 & 95 \\
$\quad$ No. positive & 0 & 86 & 6 \\
$\quad$ No. negative & 0 & 10 & 0 \\
Possibly infected (10) & 10 & 0 & 10 \\
$\quad$ No. positive & & & \\
$\quad$ No. negative & 0 & 0 & 1 \\
Uninfected (145) & 145 & 145 & 144 \\
$\quad$ No. positive & & & \\
$\quad$ No. negative & & & \\
\hline \hline
\end{tabular}

GAGATGCATGA 3' and 5' GGTTCGATTGGGGTTGGTGTAATATA $3^{\prime}$ ), and water to a final volume of $50 \mu \mathrm{l}$ in a thin-walled reaction tube. The upper phase was made of $7.5 \mu \mathrm{l}$ of the DNA sample, $2.5 \mu \mathrm{l}$ of $10 \times T a q$ polymerase buffer, $2.5 \mu \mathrm{l}$ of Taq DNA polymerase and $12.5 \mu \mathrm{l}$ of water. The PCR reaction was immediately started using a DNA thermocycler 480 (Perkin-Elmer) with the following parameters: 2 cycles at $98^{\circ} \mathrm{C}$ for $1 \mathrm{~min}$ and $64^{\circ} \mathrm{C}$ for $1 \mathrm{~min}, 33$ cycles at $94^{\circ} \mathrm{C}$ for $1 \mathrm{~min}$ and $64^{\circ} \mathrm{C}$ for $1 \mathrm{~min}$, and a final extension at $72^{\circ} \mathrm{C}$ for $10 \mathrm{~min}$. The same protocol allowed the amplification of the human $\beta$-globin sequences with the primers $5^{\prime}$ ACACAAACTGTGTTCACTAGC 3 ' and 5' CAACTTCATCCACGTTCACC 3 '. The PCR products were analysed by electrophoresis on a $2 \%$ agarose gel and visualized by ethidium bromide staining.

\section{RESULTS}

\section{Prevalence of Chagas' disease in the endemic area}

The present study was conducted in a rural setting in the Cochabamba region where no insect control programme has been implemented yet. A total of 268 school children (1-15 years old) was randomly selected to be diagnosed for Chagas' disease. Before performing the PCR diagnosis test, we first applied a serological diagnosis aimed at detecting IgG in the blood using 4 different techniques (described in the Materials and Methods section). Two further tests were performed on all children to detect possible recent infections. First, a direct examination for parasites after concentration in the buffy coat was performed. Second, an IgM-specific detection reaction was made at the Institut Pasteur. Table 1 summarizes the results. One-hundred and thirteen children $(42.2 \%)$ were positive in at least 3 of the 4 tests detecting specific IgG and/or positive in direct parasitological diagnosis (buffy coat), and were considered infected by $T$. cruzi (we will refer to them as 'confirmed chagasic patients' from now). This result shows the high prevalence and the active transmission of the disease in this region. Among the confirmed chagasic patients group, 12 patients presented a positive buffy coat and 15 a positive specific IgG reaction associated to a positive specific IgM reaction (Table 2 ) with a negative buffy coat, and were considered recently infected $(23.9 \%)$. The other 86 confirmed chagasic patients were classified as in an indeterminate state of the disease. Furthermore, 10 patients presented only a positive specific IgM detection with a negative specific IgG reaction and a negative buffy coat and were considered as possible $T$. cruzi infections $(3.7 \%$ of the entire population). We note that in this last group the majority of the patients present a high rate of IgM antibodies (Table 2). The other 145 patients with negative serological and negative buffy coat were considered free of $T$. cruzi infection.

\section{PCR diagnosis}

All 268 children previously examined were further submitted to a PCR diagnosis test. This test used specific amplification of minicircle sequences and was previously shown to be sensitive enough to detect 1 parasite in $20 \mathrm{ml}$ of blood (Britto et al. 1993). A typical result for a series of PCR tests, including the positive and negative controls systematically included, is presented in Fig. 1. We found that, out of 113 chagasic patients, 106 were PCR positive ( $93.8 \%$ ). Moreover, we did not observe significant differences in the PCR tests between the recent infections and the indeterminate group $(88.8 \%$ and $95 \%$ of positivity respectively, Chi $2=$ $1.47, P>0.05)$. In the group of non-infected children, the PCR test was positive in 1 case (see 
Table 2. Specific IgM antibodies in the blood of Bolivian children (BC = Buffy coat test $; \mathrm{IgG}=$ specific anti-Trypanosoma cruzi immunoglobulins $\mathrm{G}$.)

\begin{tabular}{|c|c|c|c|c|c|}
\hline \multirow{2}{*}{$\begin{array}{l}\text { Specific IgM } \\
\text { values }\end{array}$} & \multicolumn{2}{|c|}{$\begin{array}{l}\text { Patients status } \\
\mathrm{BC}+\end{array}$} & \multicolumn{2}{|l|}{$\mathrm{BC}-$} & \multirow{2}{*}{$\begin{array}{l}\text { Total } \\
\text { no. of } \\
\text { cases }\end{array}$} \\
\hline & $\mathrm{IgG}+$ & $\mathrm{IgG}-$ & $\mathrm{IgG}+$ & $\operatorname{IgG}-$ & \\
\hline OD ratio $<1.00$ & 8 & 1 & 86 & 145 & 240 \\
\hline $1.00<$ OD ratio $<1.10$ & 1 & 1 & 2 & 4 & 8 \\
\hline OD ratio $>1 \cdot 10$ & 0 & 1 & 13 & 6 & 20 \\
\hline
\end{tabular}

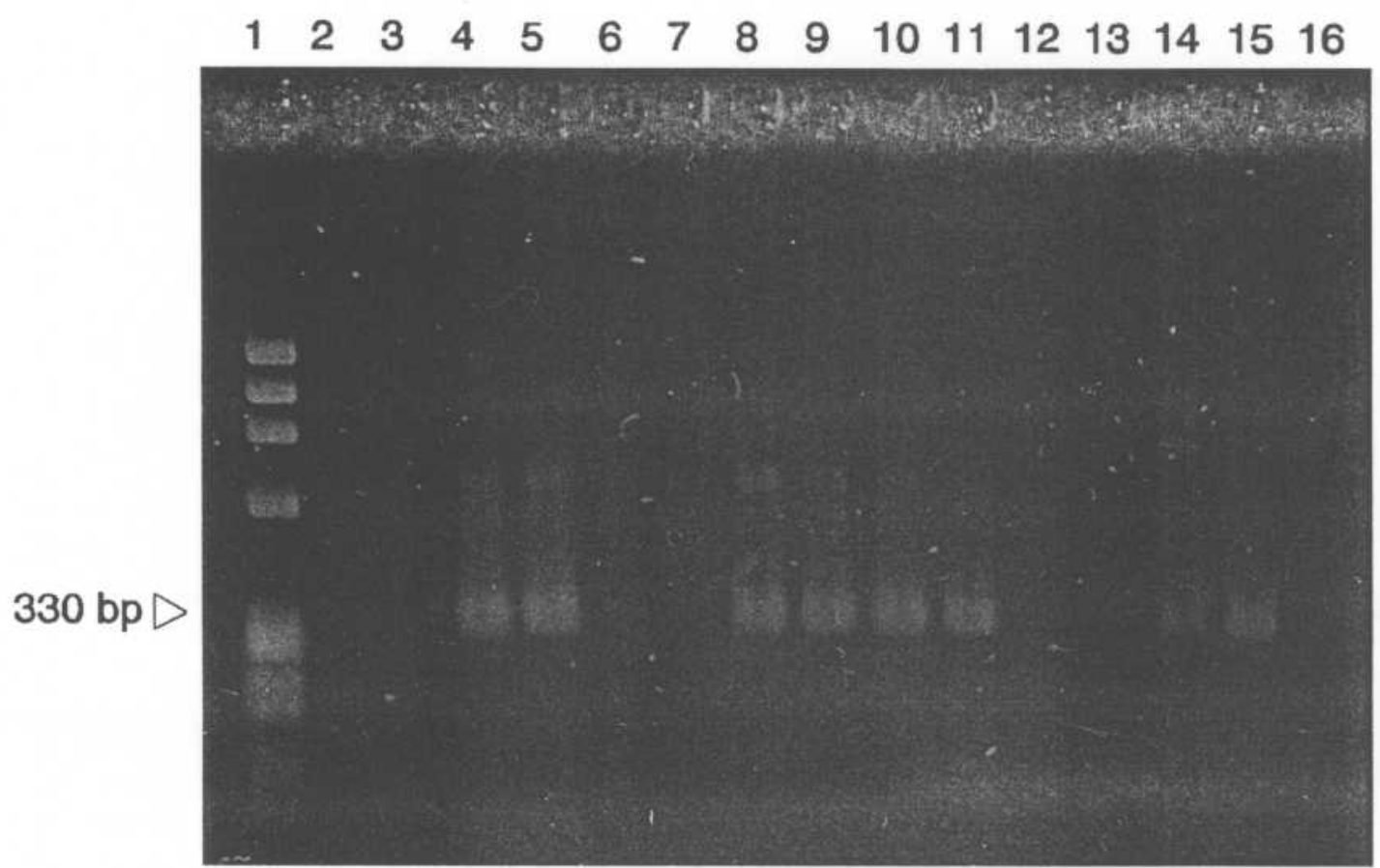

Fig. 1. Typical PCR diagnosis experiment. Lane 1, molecular weight marker ( $\Phi$ X174 DNA-Hae III digested); lanes 2 and 3, negative controls (normal individual); lanes 4 and 5-12 and 13, Bolivian children; lane 14, positive control (confirmed chagasic patient with low parasitaemia); lane 15, positive control (confirmed chagasic patient with high parasitaemia); lane 16, negative control of the reaction (no DNA added). All reactions except the positive controls were performed with duplicate DNA preparations, using 35 amplification cycles in a volume of $75 \mu 1$. Fifteen $\mu \mathrm{l}$ were applied to each gel lane, and the results were revealed using U.V. transillumination after ethidium bromide staining. All the negative DNA preparations were checked for possible inhibition using a human $\beta$-globin amplification.

Discussion section). Finally, the PCR test was always negative in the possibly infected group (only IgM positive).

It is worth noting that the PCR test reached a high level of accordance only with the specific IgG test $(96.6 \%)$. Out of 12 positive buffy coats, 11 PCR tests were positive $(91.6 \%)$. Moreover, out of 28 patients presenting positive IgM, 16 had a positive PCR test $(57 \cdot 1 \%)$. We also observed that the values of positive IgM antibodies ranged from 1.02 to 2.63 (optical density ratio) and that 20 patients present an IgM optical density ratio of $>1 \cdot 10(71.43 \%$, Table 2$)$. We did not observe significant differences in the PCR test between these 2 groups presenting low and high levels of IgM antibodies.

When comparing the results obtained in the confirmed chagasic patients group, we found that out of $18 \mathrm{IgM}$ positive cases, 14 were IgG and PCR positive, while 2 were only PCR positive and 2 only IgG positive.

\section{DISCUSSION}

The present study was intended to test the interest of PCR diagnosis for Chagas' disease in a situation of active transmission. It complements previous studies carried out in areas where transmission was stopped. In these studies the sensitivity of PCR, when compared to serology (IgG detection), was found to be dependent on the level of parasitaemia observed with the strains circulating in each area. It reached 45, 60 and $96.5 \%$ for 3 Brazilian regions where the circulating strains gave rise to low, intermediate and high parasitaemia, respectively (Britto et al. 1995 ; 
Junqueira et. al. 1996; Wincker et al. 1994a). The results of the present study demonstrate that we can expect a high degree of sensitivity in an active transmission area. This result may be related to a high frequency of re-infection, to the low immune status of the patients (perhaps in relation with their poor living conditions) or to the genetic constitution of the T. cruzi strains circulating in the area. It is worth noting that in the 3 Brazilian areas mentioned above, the transmission had been stopped and therefore the hypothesis of frequent reinfections was not applicable. On the contrary, it is known that experimental infections with different clones of $T$. cruzi induced different patterns of parasitaemia (Sanchez et al. 1990; Laurent, 1994). This supports the hypothesis of a variation of parasitaemia rates in human relating in part to the genetic constitution of $T$. cruzi clones. Further work is needed to address these points.

Taken together, all these previous results indicate that PCR, although not sufficiently sensitive to be used for Chagas' disease diagnosis alone, is the best complementary technique to serology for this purpose. Its very high specificity is also an advantage for the diagnosis of difficult cases, e.g. patients with a borderline response in serology. With the data obtained in the present work, we can discuss for the first time the interest of the PCR test for the early diagnosis of Chagas' disease. The high specificity and sensitivity of PCR are particularly important for recent infections, as the drugs presently in use for Chagas' disease treatment are much more efficient in the acute phase than in the chronic phase (De Castro, 1993). A rapid and sensitive diagnosis is therefore needed to decide the start-up of the treatment. Acute stage or initial infection is commonly defined by the presence of circulating parasites evidenced by direct parasitological examination which is difficult and depends on the microscopist. An alternative is the detection of specific anti- $T$. cruzi IgM antibodies, as these appear 3-4 days after infection, present a peak around 15-20 days later and decrease progressively (Braun \& Titto, 1985). Specific IgG antibodies are detectable 10-15 days after infection (Vattuone, Szarfman \& Gonzalez-Cappa, 1978; Schmunis et al. 1980). Consequently, patients presenting IgM antibodies associated or not with specific $\mathrm{IgG}$, are considered in the initial stage of the infection. In this last group of patients, the sensitivity of the PCR test was low $(57.1 \%)$. This may indicate that PCR is of low interest for the diagnosis of these cases or, alternatively, that the specificity of the $\operatorname{IgM}$ detection may be low and had led to some false-positive results.

The single case of a PCR-positive individual who remained negative with all other techniques may be explained either by DNA contamination, or a very recent infection not detected otherwise or a patient presenting specific immune suppression (Brenière $e t$ al. 1984). DNA contamination is extremely unlikely, as the PCR test was carried out in duplicate after 2 independent DNA extractions and was positive in both assays. A long-term follow-up of this individual will be necessary to discriminate among these hypotheses.

The analysis of the different tests obtained among the 268 patients permits proposal of a cinetic model for specific antibodies and parasitaemia: first synthesis of IgM (few days after infection) followed by synthesis of IgG and later increase of parasitaemia. This model explains 264 cases out of 268 . In particular, we observed 10 patients with positive IgM alone, 15 patients with positive IgG and IgM but with negative direct parasitaemia (buffy coat) and finally, out of 12 patients with a positive buffy coat, 8 presenting already IgG positivity without IgM positivity. If the rise in parasitaemia occurred before or simultaneously with IgG synthesis the last 2 groups would remain difficult to explain. According to this model, the PCR test would fail to diagnose only the earliest cases of infection (positive IgM antibodies alone). This work must be complemented by a follow-up of young populations presenting IgM antibodies to assess the interest of this marker compared with PCR in detecting early cases of Chagas' disease.

An overt advantage of the PCR detection of T. cruzi in blood over other methods of parasite detection as buffy coat examination, haemoculture or xenodiagnosis, is the gain of sensitivity, consistently documented in all studies performed to date. This is particularly important for epidemiological surveys, as the samplings carried out with classical methods were probably biased towards the fastest-growing strains isolated after a culture step. With the PCR test used in the present study, an amplified product corresponding to the minicircle content of a whole infective population of parasites can be obtained. Recent studies have shown that these amplified products could be useful as hybridization probes to study the strains infecting a particular patient (Britto et al. $1995 b$ ) or to look at the triatomine population in which a particular strain is circulating (Brenière $e t$ al. 1992, 1995). A future development of the present work would be the application of such hybridization techniques to study the $T$. cruzi strains involved in current transmission.

This investigation received financial support from the UNDP/World Bank/WHO Special Programme for Research and Training in Tropical Diseases (contracts $\mathbf{n}^{\circ}$ 910273 and 910276), PAPES-Fiocruz, CNPq and FINEP.

\section{REFERENCES}

alvarez, M., Cerisola, J. A. \& Rohweder, R. W. (1968).

Test de inmunofluorescencia para diagnostico de la enfermedad de Chagas. Bolletin Chileno de

Parasitologia 23, 4-9. 
AVIla, H. A., Sigman, D. S., COHEN, L. M., Millikan, R. C. \& SIMPSON, L. (1991). Polymerase chain reaction amplification of Trypanosoma cruzi kinetoplast minicircle DNA isolated from whole blood lysates: diagnosis of chronic Chagas' disease. Molecular and Biochemical Parasitology 48, 211-222.

AVILA, H. A., BORges PEREIRA, J., THIEMANN, O., DE PAIVA, E., Degrave, W., MOREl, C. M. \& SiMPSON, L. (1993). Detection of Trypanosoma cruzi in blood specimens of chronic chagasic patients by polymerase chain reaction amplification of kinetoplast minicircle DNA: comparison with serology and xenodiagnosis. Fournal of Clinical Microbiology 31, 2421-2426.

AZNAR, C., LOPEZ-BERGAMI, P., BRANDARIZ, S., MARIETTE, C., LIEGEARD, P., ALVES, M. DE C. DE D., BARRIERo, E. L., CARRASCO, R., LAFON, S., KAPLAN, D., MIGUEZ, H., CAMACHO, C., LeVitus, G., LeVIN, M. J. \& HONTEBEYRIE, M. (1995). Prevalence of anti-R-13 antibodies in human Trypanosoma cruzi infection. FEMS Immunology and Medical Microbiology 12, 231-238. BRAUN, M. \& TITO, E. (1985). Respuesta immune al Trypanosoma cruzi. Un enfoque de patogenia en la enfermedad de Chagas. Acta Physiologica Pharmacologica Latinoamericana 35, 1-47.

BRENIÈre, S. F., CARRASCO, R., MIGUEZ, H., LEMESRE, J. L. \& CARLIER, Y. (1984). Comparison of immunological tests for serodiagnosis of Chagas disease in Bolivian patients. Tropical and Geographical Medicine 37, 231-238.

BRENIÈRE, S. F., BoSSENO, M. F., REVOLLO, S., RIVERA, M. T., CARLIER, Y. \& TIBAYRENC, M. (1992). Direct identification of Trypanosoma cruzi natural clones in vectors and mammalian hosts by polymerase chain reaction amplification. American fournal of Tropical Medicine and Hygiene 46, 335-341.

BRENIÈRE, S. F., BosSENO, M. F., TELleRIA, J., CARRASCo, R., VARGAS, F., YAKSIC, N. \& NOIREAU, F. (1995). Field application of PCR diagnosis and strain typing of Trypanosoma cruzi in Bolivian triatomines. American Fournal of Tropical Medicine and Hygiene 53, 179-184. BRITTO, C., CARDOSO, M. A., WINCKER, P. \& MOREL, C. M. (1993). A simple protocol for the physical cleavage of Trypanosomsa cruzi kinetoplast DNA present in blood samples and its use in polymerase chain reaction (PCR)-based diagnosis of chronic Chagas' disease. Memorias do Instituto Oswaldo Cruz 88, 171-172.

BRItTo, C., CARDoso, M. A., MONTEIRo VANNi, C., HASSLOCHER-MORENO, A., XAVIER, S. S., OELEMANN, W., SANTORO, A., PIRMEZ, C., MOREL, C. M. \& WINCKER, P. $(1995 a)$. Polymerase chain reaction detection of Trypanosoma cruzi in human blood samples as a tool for diagnosis and treatment evaluation. Parasitology 110, 241-247.

britto, C., cardoso, M. A., ravel, C., SANTORo, A., BORGES PEREIRA, J., COURA, J. R., MOREL, C. M. \& Wincker, P. (1995b). Trypanosoma cruzi: Parasite detection and strain discrimination in chronic chagasic patients from northeastern Brazil using PCR amplification of kinetoplast DNA and non-radioactive hybridization. Experimental Parasitology 81, 462-471.

CAMARGo, M. E. (1992). An appraisal of Chagas' disease serodiagnosis. In Chagas' Disease (American Trypanosomiasis) : its Impact on Transfusion and
Clinical Medicine (ISBT Brazil 1992, ed.) pp. 165-178. ISB'T, Sao Paulo.

CHIARI, E., DIAS, J. C. P., LANA, M. \& CHIARI, C. A. (1989). Hemocultures for the parasitological diagnosis of human chronic Chagas' disease. Revista da Sociedade Brasileira de Medecina Tropical 22, 19-23.

CHOU, Q., RUSSELL, M., BIRCH, D. E., RAYMOND, J. \& BLOCH, W. (1992). Prevention of pre-PCR mis-priming and primer dimerization improves low-copy number amplifications. Nucleic Acids Research 20, 1717-1723.

DE CASTRO, S. L. (1993). 'The challenge of Chagas' disease chemotherapy: an update of drugs assayed against Trypanosoma cruzi. Acta Tropica 53, 83-98.

JUNQUEIRA, A. C. V., CHIARI, E. \& WINCKER, P. (1996). Comparison of the polymerase chain reaction with two classical parasitological methods for the diagnosis of Chagas' disease patients in a north-eastern endemic region of Brazil. Transactions of the Royal Society of Tropical Medicine and Hygiene 90, 129-132.

LA FUeNTE, C., SAUCEDO, E. \& URGEL, R. (1984). The use of microhaematocrit tubes for the rapid diagnosis of Chagas' disease and malaria. Transactions of the Royal Society for Tropical Medicine and Hygiene 78, 278-279.

LAURENT, J. P. (1994). Comparaison des proprietes biologiques de differents clones naturels de Trypanosoma cruzi. Thesès sciences, Université Montpellier II, France.

Moncayo, A. (1993). Chagas' disease. In TDR Eleventh Programme Report, pp. 67-75. World Health Organization, Geneva, Switzerland.

MOSER, D. R., KIRCHHOFF, L. V. \& DONELSON, J. E. (1989).

Detection of Trypanosoma cruzi by DNA amplification using the polymerase chain reaction. Fournal of Clinical Microbiology 27, 1477-1482.

SANCHEZ, G., WALlACE, M., Olivares, M., DIAZ, N., AGUILERA, X., APT, W. \& SOLARI, A. (1990). Biological characterization of Trypanosoma cruzi zymodemes: in vitro differentiation of epimastigotes and infectivity of culture metacyclic trypomastigotes to mice.

Experimental Parasitology 71, 125-133.

SCHMUNIS, G. A., SZARFMAN, A., COARASA, L., GUILLERON, C. \& PERAlta, J. M. (1980). Anti-Trypanosoma cruzi agglutinins in acute human Chagas' disease. American Fournal of Tropical Medicine and Hygiene 29, 170-178. STURM, N., DEGRAVE, W., MOREL, C. M. \& SIMPSON, L.

(1989). Sensitive detection and schizodeme classification of Trypanosoma cruzi cells by amplification of kinetoplast DNA sequences: use in diagnosis of Chagas' disease. Molecular and Biochemical Parasitology 33, 205-214.

TAIBI, A., GUEVARA-ESPINOSA, A., SCHÖNECK, R., YAHIAOUI, B. \& OUAISSI, A. (1995). Improved specificity of Trypanosoma cruzi identification of polymerase chain reaction using an oligonucleotide derived from the amino-terminal sequence of a $\mathrm{Tc} 24$ protein.

Parasitology 111, 581-590.

VATTUONE, N. H., SZARFMAN, A. \& GONZALEZ-CAPPA, S. M. (1978). Antibody response and immunoglobulin levels in humans with acute Chagas' disease. A following up study. American Yournal of Tropical Medicine and Hygiene 27, 473-477.

WINCKER, P., BRITTO, C., BORGES PEREIRA, J., CARDOSO, M. A., OELEMANN, W. \& MOREL, C. M. (1994a). Use of 
a simplified polymerase chain reaction procedure to detect Trypanosoma cruzi in blood samples from chronic chagasic patients in a rural endemic area. American fournal of Tropical Medicine and Hygiene 51, 771-777.

WINCKER, P., BOSSENO, M. F., BRITTO, C., YAKSIC, N.,
CARDOSO, M. A., MOREL, C. M. \& BRENIERE, S. F. (1994b). High correlation between Chagas' disease serology and PCR-based detection of Trypanosoma cruzi kinetoplast DNA in Bolivian children living in an endemic area. FEMS Microbiology Letters 124, 419-424. 